\title{
Recent changes in wetlands on the Tibetan Plateau:
}

\section{A review}

\author{
ZHAO Zhilong ${ }^{1,4}$, 'ZHANG Yili ${ }^{1,2}$, 'LIU Linshan' ${ }^{1}$, LIU Fenggui ${ }^{3}$, ZHANG Haifeng ${ }^{3}$
}

1. Key Laboratory of Land Surface Pattern and Simulation, Institute of Geographic Sciences and Natural Resources Research, CAS, Beijing, 100101, China;

2. CAS Center for Excellence in Tibetan Plateau Earth Sciences, Beijing 100101, China;

3. College of Biological and Geographic Sciences, Qinghai Normal University, Xining 810008, China;

4. University of Chinese Academy of Sciences, Beijing 100049, China

\begin{abstract}
About $80 \%$ of global wetland resources are degrading or disappearing; thus the wetland ecosystem has become one of the most seriously threatened ecosystems in the world. As an area sensitive to global changes and acting as a security barrier for the Asian ecosystem, the Tibetan Plateau has about $13.19 \times 10^{4} \mathrm{~km}^{2}$ of wetlands of special significance within China. With the increasing application of remote sensing technology to wetland research, Tibetan Plateau wetland research has entered a period of rapid development. This paper summarizes the remote sensing research literature of the Tibetan Plateau wetlands from 1992 to 2014, and is intended to provide references for future research into the wetlands of the Tibetan Plateau. We have reviewed monitoring methods, research topics, and existing problems. Our review has revealed the following characteristics: (1) Over the past 40 years, the research paradigm of the Tibetan Plateau wetlands has undergone dynamic changes in the monitoring of wetland areas, landscape patterns and the eco-environment based on remote sensing technology. Attention has also been focused on constructing models with an ecological system perspective and analyzing three patterns of change trends within the Tibetan Plateau wetlands. (2) The results of Tibetan Plateau wetland research based on remote sensing were as follows: (a) between 1970 and 2006, the Tibetan Plateau wetland area decreased overall at a rate of $0.23 \% / a$, and the landscape diversity declined at a rate of $0.17 \% / a$; (b) by contrast, between 1976 and 2009, the lake area of the inland river basins in the Tibetan Plateau increased at a rate of $0.83 \% / a$; and (c) the change trend in the Tibetan Plateau wetlands was controlled by climate change. Current problems relating to remote sensing (RS)-based research in the Tibetan Plateau wetlands are computer interpretation accuracy and the processing precision of cloud removal, and the lack of a comprehensive
\end{abstract}

Received: 2014-11-16 Accepted: 2014-12-12

Foundation: Strategic Priority Research Program of the Chinese Academy of Sciences, No.XDB03030500; The National Key Technology Research and Development Program, No.2013BAC04B02, No.2012BAC06B00; The Key Foundation Project of Basic Work of the Ministry of Science and Technology of China, No.2012FY111400

Author: Zhao Zhilong (1988-), PhD Candidate, specialized in land-use and land-cover change and physical geography.

E-mail: geozhao@163.com

*Corresponding author: Zhang Yili, Professor, E-mail: zhangyl@igsnrr.ac.cn

Liu Linshan, PhD, E-mail: liuls@igsnrr.ac.cn

This paper has been published in Progress in Geography (Chinese edition) and revised partially. 
overview of the Tibetan Plateau wetland system. Finally, based on the review, some key activities for future study have been proposed, as follows: (1) Strengthening the integration of the Tibetan Plateau wetland research with remote sensing research; (2) discussing the response and adaptation mechanisms of the Tibetan Plateau wetland ecosystem within the context of global change; (3) strengthening the integration of remote sensing (RS), geographic information system (GIS), and global positioning system (GPS), and promoting the construction of a Tibetan Plateau wetland information platform.

Keywords: Tibetan Plateau; wetland; research in remote sensing

\section{Introduction}

Wetlands are areas of marsh, fen, peatland or water, whether natural or artificial, permanent or temporary. The water may be static or flowing, fresh, brackish or salt, and includes areas of marine water, the depth of which at low tide does not exceed six meters. These are the definitions of wetland cited by the Ramsar Convention on Wetlands (The Ramsar Convention Bureau, 2000) and cited in Standards of Surveying Wetland Resources of China (provisional version) (SFAC, 2008).

Wetlands represent one of the most biodiverse types of ecological landscapes and one of the most important human survival environments (Chen, 1995). Of their total area of approximately $860 \times 10^{4} \mathrm{~km}^{2}$ worldwide, it is estimated that $80 \%$ of wetlands are degrading or disappearing (Sun, 2000; Sun et al., 2006). Therefore, the wetland ecosystem has become one of the most seriously threatened ecosystems worldwide (Lemly et al., 2000). As a country with one of the richest wetland resources, China has $65.94 \times 10^{4} \mathrm{~km}^{2}$ of wetlands, ranking fourth in size globally and accounting for $8 \%$ of all the world's wetlands (Zhao, 1999; Sun et al., 2006). Moreover, it encompasses almost all of the wetlands defined by the Ramsar Convention, in addition to its unique Tibetan Plateau wetland (Yang, 2002b). Covering an area of about $13.19 \times 10^{4} \mathrm{~km}^{2}$ (Xing et al., 2009), under an alpine climate, the Tibetan Plateau wetland includes lakes, rivers, marshes and reservoirs; it comprises the largest wetland in China (Zhao, 1999), accounting for 20\% of China's wetlands, and the lake area alone constitutes half of the lake area of the entire country (Yan and Qi, 2012). The Tibetan Plateau is an area important to wetland distribution in China and it is an area sensitive to global climate change (Xie et al., 2003); it also acts as an ecological security barrier for China, and even for Asia as a whole (Sun et al., 2012). Thus, the Tibetan Plateau wetland plays an important role in research into global climatic and environmental change (Bai et al., 2004).

Prior to the 1980s, a number of scientific investigations carried out basic surveys of wetland types and extent, terrain, soil, climate, fauna and flora within the Tibetan Plateau (Chai and Jin, 1963; Guan and Chen, 1980; Zhao et al., 1981; Chen and Fan, 1983; Sun et al., 1987). Since then, remote sensing technology has been applied to wetland research in this region. Furthermore, owing to its broad observation range, large data capacity, rapid access to information, and high comparability, remote sensing has been widely used in wetland transformation, area change, landscape pattern evolution, and monitoring of the eco-environment. This paper summarizes the development and use of remote sensing of the Tibetan Plateau wetlands and discusses the trends in this field, so as to provide an information resource for future research. 


\section{Progress in theory and method of the Tibetan Plateau wetland research}

\subsection{Wetland classification based on remote sensing}

A scientific classification system for wetlands is one of the core issues of wetland science and is also a representation of wetland science development (Yang, 2002a). Generally, there are two types of classification, based on causes or features (Ni et al., 1998). Because of the uniqueness of the Tibetan Plateau, Chinese researchers have accordingly proposed classification systems with different spatial scales to meet the needs of remote sensing research on this wetland (Zhao, 1999; Chen et al., 2002; Zhang et al., 2007). One such system classifies wetlands in the Three-River Source region of the central Tibetan Plateau into moor, lake, river, and riverbed, within particular drainage basins (Li et al., 1998). Another system classifies wetlands in the Lhasa River basin of the southern valley of the Tibetan Plateau into open water, alpine meadow, grass marsh, shrubby swamp, forest wetland and beach land, and then into 13 further subcategories (Wang, 2010). Additionally, the Forestry Department of the Tibet Autonomous Region proposed its own classification system for the same region, with four categories - river, lake, marsh and artificial wetland - and 17 subcategories (FBTAR, 2011). The application of remote sensing technology to the classification of alpine wetlands is primarily based on spectrum features, which differ among various landmarks. An accurate classification system must be based on actual local conditions, taking into account the spatial scale and complexity of the local wetland types. The systems used to classify the Tibet Autonomous Region and the Lhasa River basin represent a remarkable resource for the classification of wetlands, both at the Tibetan Plateau scale and at a watershed scale.

\subsection{Identification and extraction of wetland information}

The identification and extraction of wetland information form the foundation of wetland change analysis, and also form the basis on which the classification, protection, and scientific management of wetland ecosystems depend. Various different methods are applied within this field - visual interpretation, human-computer interpretation, or automatic computer interpretation - depending upon the types of remote sensing images that are required at particular times (Table 1) (Li et al., 2007).

\subsubsection{Wetland information extraction based on visual interpretation}

Visual interpretation is a comprehensive analysis based on the interpreter's experience, combined with auxiliary information such as elevation data, type of terrain and soil, and land use. This method is especially superior to computer interpretation in dealing with spatial relationships and has been used to analyze change trends in the wetlands of Zoige (Zhou et al., 1999; Shen et al., 2005) and the source region of the Yangtze River (Huang et al., 2011). And the change regularities of wetland area and other indicators have also been found during the 1970s-2000s. Visual interpretation remains limited by its low efficiency, and by its requirement for a large amount of background knowledge, and the quality of interpretation is related to the interpreter's experience and familiarity with the study area.

2.2.2 Wetland information extraction based on automatic computer interpretation

With the development of digital image interpretation methods, computer-based interpretation is set to play an increasingly important role in the future development of wetland identifica- 
Table 1 Performance of the different types of imaging techniques used in remote sensing of the Tibetan Plateau wetlands (Li et al., 2007)

\begin{tabular}{|c|c|c|c|c|c|c|c|}
\hline \multirow{2}{*}{$\begin{array}{c}\begin{array}{c}\text { Resolution } \\
\text { parameter }\end{array} \\
\text { Resolution grade }\end{array}$} & \multicolumn{3}{|c|}{ Spatial resolution } & \multicolumn{2}{|c|}{ Spectral resolution } & \multicolumn{2}{|c|}{ Time phase } \\
\hline & High & Moderate & Low & Hyper-spectral & Multi-spectral & Single & Multiple \\
\hline Data source & $\begin{array}{l}\text { Aerial } \\
\text { images, } \\
\text { ALOS }\end{array}$ & $\begin{array}{l}\text { Landsat, } \\
\text { SPOT, } \\
\text { CBERS, } \\
\text { HJ-1A/1B, } \\
\text { ENVISAT }\end{array}$ & $\begin{array}{l}\text { MODIS, } \\
\text { AVHRR }\end{array}$ & $\begin{array}{l}\text { MODIS, } \\
\text { HJ-1A }\end{array}$ & $\begin{array}{l}\text { Landsat, } \\
\text { SPOT, } \\
\text { CBERS, } \\
\text { HJ-1B, } \\
\text { AVHRR, } \\
\text { ALOS, } \\
\text { ENVISAT }\end{array}$ & $\begin{array}{l}\text { Remote } \\
\text { sensing } \\
\text { images }\end{array}$ & $\begin{array}{l}\text { Remote } \\
\text { sensing im- } \\
\text { ages }\end{array}$ \\
\hline Advantages & $\begin{array}{l}\text { High pre- } \\
\text { cision, } \\
\text { multi-level } \\
\text { classify- } \\
\text { ing, ap- } \\
\text { plied in } \\
\text { small scale }\end{array}$ & $\begin{array}{l}\text { Low price, } \\
\text { accessible, } \\
\text { applied in } \\
\text { moderate } \\
\text { scale } \\
\text { long-time } \\
\text { series of } \\
\text { Landsat } \\
\text { data, } \\
\text { widely } \\
\text { used in } \\
\text { Tibetan } \\
\text { Plateau } \\
\text { wetland } \\
\text { research }\end{array}$ & $\begin{array}{l}\text { Low price, } \\
\text { accessible, } \\
\text { applied on a } \\
\text { large scale }\end{array}$ & $\begin{array}{l}\text { Narrow bands, } \\
\text { multiple } \\
\text { bands, large } \\
\text { information, } \\
\text { continuous } \\
\text { spectra in pix- } \\
\text { els, high pre- } \\
\text { cision, applied } \\
\text { to vegetation } \\
\text { monitoring, } \\
\text { vegetation } \\
\text { classification, } \\
\text { and biomass } \\
\text { estimation }\end{array}$ & $\begin{array}{l}\text { High preci- } \\
\text { sion, simple } \\
\text { processing, } \\
\text { widely used } \\
\text { in Tibetan } \\
\text { Plateau wet- } \\
\text { land research }\end{array}$ & $\begin{array}{l}\text { Quickly } \\
\text { extracted } \\
\text { information, } \\
\text { good com- } \\
\text { patibility } \\
\text { with high } \\
\text { spatial reso- } \\
\text { lution im- } \\
\text { ages }\end{array}$ & $\begin{array}{l}\text { Provides a } \\
\text { wealth of in- } \\
\text { formation, higl } \\
\text { precision, mul- } \\
\text { tiple phases, } \\
\text { applied to wet- } \\
\text { land monitor- } \\
\text { ing, identifyinধ } \\
\text { different ob- } \\
\text { jects with same } \\
\text { spectrum and } \\
\text { same object } \\
\text { with different } \\
\text { spectra, widely } \\
\text { used in Tibetan } \\
\text { Plateau wetlan } \\
\text { research }\end{array}$ \\
\hline Disadvantages & $\begin{array}{l}\text { Large data, } \\
\text { complex } \\
\text { process- } \\
\text { ing, high } \\
\text { price, } \\
\text { ALOS lost } \\
\text { connection } \\
\text { from } 2011\end{array}$ & $\begin{array}{l}\text { Hard to } \\
\text { carry out } \\
\text { multi-level } \\
\text { classifica- } \\
\text { tion, } \\
\text { ENVISAT } \\
\text { lost con- } \\
\text { nection } \\
\text { from } 2012\end{array}$ & $\begin{array}{l}\text { Hard to } \\
\text { carry out } \\
\text { multi-level } \\
\text { classifica- } \\
\text { tion, poor } \\
\text { classifying } \\
\text { performance }\end{array}$ & $\begin{array}{l}\text { Difficult to } \\
\text { obtain, com- } \\
\text { plex process- } \\
\text { ing, need to } \\
\text { combine with } \\
\text { high or mod- } \\
\text { erate spatial } \\
\text { resolution } \\
\text { images }\end{array}$ & $\begin{array}{l}\text { Wide bands, } \\
\text { fewer bands, } \\
\text { less informa- } \\
\text { tion, discon- } \\
\text { tinuous spec- } \\
\text { tra, generally } \\
\text { applied in } \\
\text { second-level } \\
\text { classification }\end{array}$ & $\begin{array}{l}\text { Less infor- } \\
\text { mation, low } \\
\text { precision, } \\
\text { represent } \\
\text { objects' } \\
\text { information } \\
\text { in one phase, } \\
\text { barely used }\end{array}$ & $\begin{array}{l}\text { Complex } \\
\text { processing }\end{array}$ \\
\hline
\end{tabular}

tion (Zhou et al., 2006).

(1) Automatic computer interpretation based on a single classifier

Along with the development of computer image processing technology, new automatic classification methods have emerged based on a single classifier, including object-oriented classification, decision-tree classification based on knowledge, artificial neural network classification, and support vector machine classification (Bai and Wang, 2005). Some researchers have studied the classification of wetlands in the Three-River Source region (Zou et al., 2011) and the greater Himalayan region (ICIMOD, 2009; Li et al., 2012) based on a decision-tree model. Object-oriented classification has been applied to the analysis of the structure and spatial distribution of wetlands in the Dam Qu River basin associated with the Yangtze River source region, and a wetland classification system suited to a high-altitude river-source region has also been considered (Zhang, 2011). However, not all wetland types can be extracted by means of a single classifier, which limits the degree of precision that can be attained with this system of classification.

(2) Automatic computer interpretation based on compound classification

The way of thinking and methods of combining multiple classifiers have arisen over the past few years and have been used in remote sensing image classification (Bai and Wang, 2005). Compound classification identifies remote sensing image information by combining 
different classifiers-an universal trend in the development of wetland remote sensing monitoring (Li et al., 2007). Researchers have applied both a spectrum-photometric method normalized difference of water index (NDWI) or modified normalized difference water index (MNDWI)-and unsupervised classification to extract the wetlands of Maduo County. MNDWI proved to be the better choice (Yang et al., 2012). Supervised classification, maximum likelihood classification, and visual interpretation were all used to study land-cover types in the Three-River Source region (Wang et al., 2007). Automatic computer interpretation based on compound classification is not only the preferred choice for wetland classification, based on comparisons of extraction precision for the individual classification methods available, but also improves precision by combining these classification methods in an optimal manner.

\section{Progress in spatio-temporal change of the Tibetan Plateau wetlands}

\subsection{Study regions and periods}

Since the first Landsat satellite was launched into space in 1972, remote sensing has played an increasingly important role in analyzing wetland changes. It is now considered to be the most important tool in monitoring wetlands (Ozesmi and Bauer, 2002). Only since the 1980s has remote sensing been applied to Tibetan Plateau wetland research, when researchers from the Northeast Institute of Geography and Agroecology, Chinese Academy of Sciences and the Northwest Institute of Plateau Biology, Chinese Academy of Sciences (Chen et al., 1992; Li et al., 1998; Zhao, 1999) began to investigate plateau wetland resources using this technology. Literature on Tibetan Plateau wetland research based on remote sensing data has been published continuously since 1992 (Chen et al., 1992) and has proliferated since 2000. Most of this research has been focused upon representative medium- or small-scale areas. Examples of medium-scale areas on which research has been conducted include: the Zoige plateau (Zhou et al., 1999; Wang et al., 2001; Yong et al., 2003; Sun, 2009), the Lhasa River basin (Zhang et al., 2000; Wang, 2010), the Yarlung Tsangpo basin (Li et al., 2013a), the Himalayan region ( $\mathrm{Li}, 2010$; Nie, 2010), the Three-River Source region (Li et al., 1998; Feng et al., 2006; Chen, 2012), the Qilian Mountains (Li et al., 2003; Hirota et al., 2007), and the area alongside the Qinghai-Tibet railway (Wang, 2008). However, corresponding research on large-scale areas (He et al., 2007; Tan et al., 2011) has been less frequent, especially in the Chiangtang Plateau, the Ali (Ngari) Plateau, and the Qaidam Basin (Zhang et al., 2007). Moreover, research into small-scale areas has mainly been focused on lake wetlands (Chen et al., 1992; Chen et al., 2001; Yuan et al., 2002; Zong et al., 2004; Zhao, 2008; Bian et al., 2010a; Wang et al., 2010; Zhou, 2011; Kropacek et al., 2012; Shang and Yang, 2012; Zhang et al., 2012a; Nie et al., 2013a; Sun et al., 2013). Furthermore, the RS-based Tibetan Plateau wetland research has mainly been limited to the years 1970, 1975, 1990, 2000, 2005, and 2010, essentially recording inter-decadal changes in the Tibetan Plateau wetland since 1970.

\subsection{RS-based monitoring of changes in wetland areas and lakes changes in three di- mensions}

\subsubsection{Wetland area changes}

The monitoring of changes in area forms the basis of wetland change monitoring. Research 
on wetland area changes in the Tibetan Plateau since 1970 has revealed the following results (Table 2):

(1) A large number of wetlands on the Tibetan Plateau are degrading (Zhang et al., 2010) or disappearing (Zhang et al., 2000; Li et al., 2009; Zhang et al., 2011a; Shang and Yang, 2012); such degradation is widespread from the periphery to the core of the plateau.

(2) The rate of wetland area changes shows obvious vertical differentiation; for example, from 1985 to 2005, the wetland area in the Yarlung Zangbo River Valley increased by 0.37\% at an altitude above $4500 \mathrm{~m}$ but decreased by $0.42 \%$ at 3500-4000 m (Li et al., 2013a).

(3) Area changes in different wetland types show significant differences; for example, between 1976 and 2006, the natural wetlands of the Lhasa River basin decreased by 9\%,

Table 2 Wetland change data on the Tibetan Plateau

\begin{tabular}{|c|c|c|c|c|c|c|}
\hline Study region & $\begin{array}{l}\text { Study } \\
\text { period }\end{array}$ & $\begin{array}{l}\text { Wetland } \\
\text { types }\end{array}$ & $\begin{array}{c}\text { Study } \\
\text { content }\end{array}$ & $\begin{array}{l}\text { Rate/ } \\
\text { value }\end{array}$ & $\begin{array}{c}\text { Annual } \\
\text { rate/value }\end{array}$ & Literature \\
\hline \multirow[t]{4}{*}{ Tibetan Plateau } & 1970s-2006 & Wetland & Area & $-8.13 \%$ & $-0.23 \%$ & Jiang et al., 2012 \\
\hline & $1970-2011$ & Lake & $\begin{array}{l}\text { Water } \\
\text { storage }\end{array}$ & $92.43 \mathrm{~km}^{3}$ & $2.2 \mathrm{~km}^{3} / \mathrm{a}$ & Song et al., 2013a \\
\hline & 2003-2009 & Lake & Depth & & $0.20 \mathrm{~m} / \mathrm{a}$ & Phan et al., 2012 \\
\hline & 2003-2009 & Lake & Depth & & $0.20 \mathrm{~m} / \mathrm{a}$ & Zhang et al., 2011b \\
\hline \multirow{4}{*}{$\begin{array}{l}\text { Inland basin of } \\
\text { Tibetan Plateau } \\
\text { Qomolangma } \\
\text { Region }\end{array}$} & $1976-2009$ & Lake & Area & $27.3 \%$ & $0.83 \%$ & Li et al., 2011 \\
\hline & $1976-2006$ & Wetland & Area & $-0.91 \%$ & $-0.03 \%$ & Nie, 2010 \\
\hline & $1976-2006$ & Swamp & Area & $-3.84 \%$ & $-0.13 \%$ & Nie, 2010 \\
\hline & $1990-2010$ & Lake & Area & $17.11 \%$ & $0.81 \%$ & Nie et al., 2013b \\
\hline \multirow[t]{4}{*}{$\begin{array}{l}\text { Lhasa River } \\
\text { basin }\end{array}$} & $1976-2006$ & Wetland & Area & $-8.8 \%$ & $-0.28 \%$ & Wang et al., 2010 \\
\hline & $1976-2006$ & Swamp & Area & $-11.94 \%$ & $-0.39 \%$ & Wang et al., 2010 \\
\hline & $1976-2006$ & Lake & Area & $-2.59 \%$ & $-0.09 \%$ & Wang et al., 2010 \\
\hline & $1976-2006$ & River & Area & $-8.72 \%$ & $-0.29 \%$ & Wang et al., 2010 \\
\hline \multirow[t]{3}{*}{$\begin{array}{l}\text { Qinghai Lake } \\
\text { basin }\end{array}$} & $1977-2004$ & Wetland & Area & $-3.71 \%$ & $-0.14 \%$ & Li et al., 2009 \\
\hline & $1977-2004$ & Swamp & Area & $0.36 \%$ & $0.01 \%$ & Li et al., 2009 \\
\hline & $1988-2010$ & Lake & Area & $2.96 \%$ & $0.13 \%$ & $\begin{array}{l}\text { Liu et al., } 2008 \\
\text { Liu et al., } 2013\end{array}$ \\
\hline \multirow[t]{4}{*}{$\begin{array}{l}\text { Three-river } \\
\text { source region }\end{array}$} & $1990-2007$ & Wetland & Area & $-11.18 \%$ & $-0.66 \%$ & Chen et al., 2012 \\
\hline & $1990-2007$ & Swamp & Area & $-16.73 \%$ & $-0.98 \%$ & Chen et al., 2012 \\
\hline & $1990-2007$ & Lake & Area & $-8.29 \%$ & $-0.49 \%$ & Chen et al., 2012 \\
\hline & $1990-2007$ & River & Area & $-8.87 \%$ & $-0.52 \%$ & Chen et al., 2012 \\
\hline \multirow[t]{4}{*}{ Zoige Plateau } & 1989-2004 & Wetland & Area & $-12.89 \%$ & $-0.42 \%$ & Wang et al., 2007 \\
\hline & $1966-2000$ & Swamp & Area & $-0.35 \%$ & $-0.01 \%$ & Bai et al., 2013 \\
\hline & $1966-2000$ & Lake & Area & $-0.59 \%$ & $-0.02 \%$ & Bai et al., 2013 \\
\hline & $1966-2000$ & River & Area & $-1.03 \%$ & $-0.03 \%$ & Bai et al., 2013 \\
\hline Banyou Marsh & $1994-2008$ & Swamp & Area & $-48.16 \%$ & $-3.44 \%$ & Xu et al., 2014 \\
\hline Qaidam Basin & $1956-2000$ & Wetland & Area & $-36.14 \%$ & $-0.80 \%$ & Zhang et al., 2007 \\
\hline
\end{tabular}

* The definitions of wetland in this table are cited from the Ramsar Convention on Wetlands (2000), they are areas of marsh, fen, peatland or water. 
whereas the artificial wetlands increased by 2.7\% (Wang, 2010).

(4) Wetland changes display distinct seasonal, inter-annual and inter-decadal characteristics, as follows:

(a) Seasonal characteristics: for example, lakes located in the inland basin of the Tibetan Plateau show stability between September and December every year, with a maximum area change rate of $2 \%$ (Li et al., 2011).

(b) Inter-annual characteristics: for example, the area and the water volume increased at rates of $2.06 \mathrm{~km}^{2} / \mathrm{a}$ and $1.60 \times 10^{8} \mathrm{~m}^{3} / \mathrm{a}$, respectively, between 1971 and 1991 , whereas the area and the water volume increased at rates of $4.01 \mathrm{~km}^{2} / \mathrm{a}$ and $3.61 \times 10^{8} \mathrm{~m}^{3} / \mathrm{a}$, respectively, between 1992 and 2004 (Zhu et al., 2010).

(c) Inter-decadal characteristics, 1950s-2000s:

During the 1950s to 2000s, wetlands kept a continuous decrease of area in the Tibetan Plateau (Figures 1). In the 1990s, the wetlands had a sharp shrinkage in the whole plateau (Figures 2). Decreasing amplitude of wetland area in the Tibetan Plateau ranged from $-5.57 \%$ to $-9 \%$. After 2000, most wetlands of the plateau were still in a shrinkage condition, except for wetlands of Maduo County (Tian et al., 2011), Qinghai Lake basin (Li et al., 2009) and middle reaches of Yongzhu Zangbo River (Xu et al., 2014) showed an increasing trend. During the 2000s, the swamps of the inflow regions continued to shrink on a large scale (Figures 2), whereas lake wetlands tended to increase (Zhang et al., 2014a).

Since 1956, there was a difference in the wetland change between the eastern and western parts of the Tibetan Plateau. The average annual rate of decrease in the eastern part of the Tibetan Plateau was extremely higher than that of the other parts (Figures 1). During the 1950s to 2000s, the wetlands of Qinghai showed continual degradation, especially in the 1990s, there was a great shrinkage in the wetlands of the province. Only some lakes were reported to expand during the past 50 years. For example, Qinghai Lake increased slightly by $0.71 \%$ during the 1980 s, and it expanded markedly by $4.16 \%$ in the 2000 s (Liu and Liu, 2008; Liu et al., 2013). The wetland change trends in area showed a difference between the southern and northern parts of the Tibetan Autonomous Region. Since the 1990s, swamps of the Qiangtang Plateau have shown a continual sharp downtrend, but some lakes of the plateau have increased dramatically in area. For example, the wetlands of Bankog Co (Lake) increased markedly by $27.94 \%$ during the 1990s (Zhao et al., 2006). In contrast, wetlands of the southern river valleys of the Tibetan Plateau have shown a continual shrinkage over the period 1970s to 2000s. Wetlands of Gannan Tibetan Autonomous Prefecture and Napahai Wetland of Yunnan Province also have significantly shrunk since the 1990s (Figure 2).

\subsubsection{Lake changes in three dimensions}

(1) Changes in lake area have occurred in various regions of the Tibetan Plateau during different periods (Table 2). These area changes have shown:

(a) Reduction with continual or annual fluctuations: for example, the wetland area of Dagze Co in Nima county diminished at a rate of $0.325 \mathrm{~km}^{2} /$ a between 1976 and 2000 (Qiao et al., 2010), while those of Peiku Co near Mount Qomolangma region decreased only slightly - by $0.15 \%$ - during the 1970 s, yet decreased markedly - by $2.53 \%$ - in the 1990 s, and expanded slightly - by $0.82 \%$ - in 2000 , then decreased even further - by $1.98 \%$ - after 2000 (Nie et al., 2013b). 


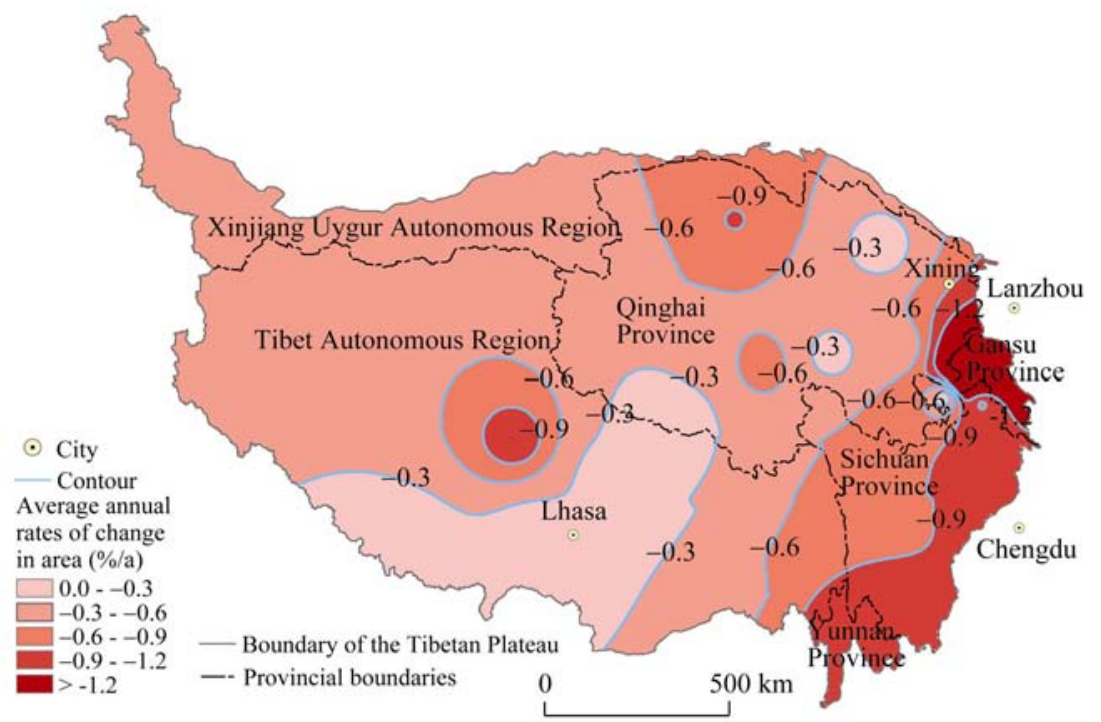

Figure 1 Rates of change in wetland area within different regions of the Tibetan Plateau since 1956 (Figures 1 and 2 are made by data reanalysis of 60 papers from 28 cases for wetland research in the Tibetan Plateau. The boundary of the Tibetan Plateau is taken from Zhang et al., 2014b)
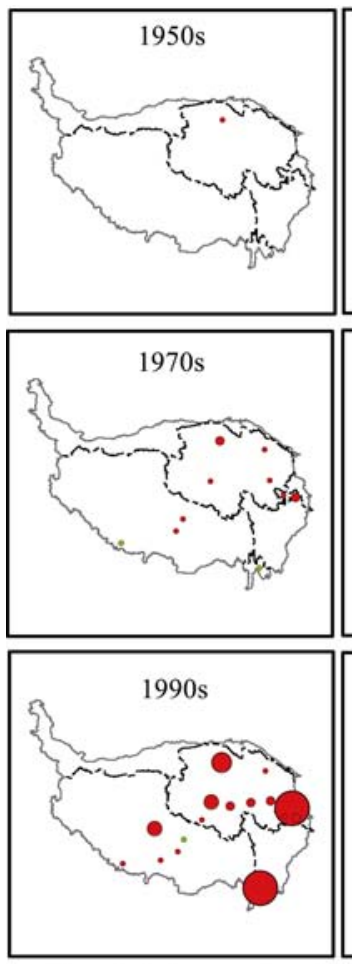

Decadal

(a)

- $0-5$

(b)

$0-10$

5-10

10-20

10-15 20-30

Region showing increase
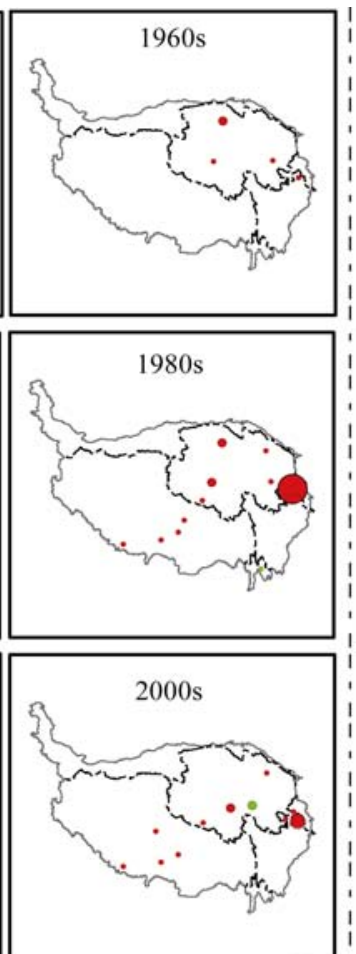

(a)

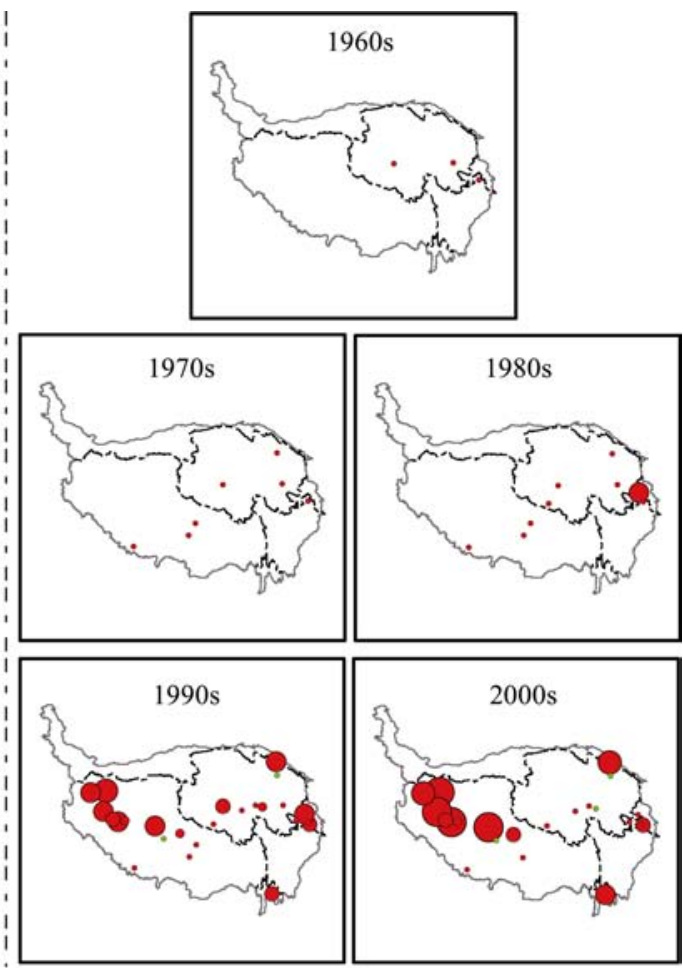

(b)

Figure 2 Decadal variation amplitude of wetland (a) and swamp (b) within different regions of the Tibetan Plateau from 1950s to 2000s 
(b) Alternation between reduction in area and expansion: the lake area of Chiangtang Nature Reserve decreased by $16.1 \%$ between 1975 and 1990, yet it increased by $74.2 \%$ between 1990 and 2005 (Li et al., 2013b).

(c) Significant annual increases: the wetland area of Seling Co expanded to $152.61 \mathrm{~km}^{2}$ between 1975 and 1990 and to $440.81 \mathrm{~km}^{2}$ between 1999 and 2010 (Lei et al., 2013).

(2) Generally, the depth of the lakes on the Tibetan Plateau increased each year between 2003 and 2009, at a rate of $0.20 \mathrm{~m} / \mathrm{a}$ (Zhang et al., 2011b; Phan et al., 2012).

For example, the depth of Qinghai Lake increased at a rate of $0.11 \mathrm{~m} / \mathrm{a}$ and that of Namco Lake at a rate of $0.25 \mathrm{~m} / \mathrm{a}$ (Zhang et al., 2011b).

(3) Research into the water storage of the plateau lakes, based on RS-based monitoring and a dynamic simulation model, has revealed that changes have occurred since the 1970s.

For example, the water storage of the lakes on the Tibetan Plateau increased by $2.2 \mathrm{~km}^{3}$ every year between 1970 and 2011 (Song et al., 2013b).

\subsection{Monitoring the evolution of wetland landscape patterns}

Landscape pattern refers to the spatial structural features of the landscape, including the type, the quantity, the spatial distribution, and the configuration of the component units (Wang and Li, 1997). Monitoring the evolution of the landscape patterns of wetlands involves recording changes in the spatial structural features of wetland landscapes. To date, in the Tibetan Plateau this research has mainly been conducted by constructing indexes with various focuses based on factors such as patch numbers, patch area, landscape type, and landscape area in order to analyze the spatial structural change throughout various periods. Research since 1970 has revealed the following results.

(1) Using a patch scale, changes in the patch area and density of various wetlands showed noticeable regional differences. For example, the patch density of the lake wetlands in the Zoige Plateau increased by $2.31 \%$ from the 1970 s until 2006, which indicated that the wetlands were fragmenting, whereas the patch density of the salt marshes decreased by $27.27 \%$ over the same period, representing a steady growth (Sun, 2009). Moreover, the patch density of the lake wetlands in the Lhasa River basin decreased by 0.05\% between 1988 and 2006 (Wang, 2010).

(2) Using a landscape scale, significant regional differences in wetland landscape diversity, distribution evenness of types, and fragmentation have been recorded. Between 1990 and 2006, the change rate of landscape diversity for the Tibetan Plateau wetland was $-2.82 \%$, which indicates a reduction in landscape diversity and structural complexity, and thus represents a degradation of the wetlands (Xing et al., 2009). However, for the Zoige Plateau the landscape diversity index revealed a decrease followed by an increase between 1990 and 2007, and there was a rise of $0.28 \%$ between 2000 and 2007 (Deng, 2010). Overall, both scales have revealed a degradation of the Tibetan Plateau wetland in recent years.

\subsection{Monitoring of ecological and environmental changes in wetlands}

Research into the ecological and environmental changes in the Tibetan Plateau wetland, using remote sensing technology, refers to studies of the spatial pattern, health status, function, and services of an ecosystem, as well as of the vegetation biomass and ecological flow requirements of the wetland. Comprehensive research has been conducted on the changes in 
the wetland eco-environment of various regions of the Tibetan Plateau during the period 1970s-2010s. This research has revealed the following results.

(1) Dramatic ecological and environmental changes have taken place in the Tibetan Plateau. Regions with "mild" and "moderate" ecological and environmental change account for $36.6 \%$ of the Tibetan Plateau. Particular environmental deterioration has occurred in the wetlands around Qinghai Lake (Zhang, 2008).

(2) Differences in the background eco-environment lead to fluctuations in ecological and environmental changes (Zhang, 2008).

(3) Xie et al. (2003) reported the wetland ecosystem service value to be $1371.7 \times 10^{8}$ yuan/a, accounting for $14.7 \%$ of the total ecosystem value of the Tibetan Plateau each year.

(4) The ecological health of wetlands differs among regions. In the Lhasa River basin, the wetland ecosystem is thriving in the upper reaches because of abundant water and a smaller population and livestock. In contrast, it is in moderate condition in the middle reaches where there is a high sensitivity and vulnerability to degradation - and it is in poor condition in the lower reaches because of the dense population (Wang, 2010).

Additionally, related research has been conducted using remote sensing technology combined with mathematical modeling and computer technology, in the following ways:

(1) Analyzing the spatial distribution of the wetland ecosystem net primary productivity (NPP) and its relationship with terrain; monitoring seasonal and interannual changes in NPP; and researching the mechanism of NPP differentiation among various vegetation regions, and then determining the health status of the wetland ecosystem. For example, between 2000 and 2009, the wetland showed a slight degradation, affecting $67 \%$ of the total area (Bian et al., 2010b).

(2) Estimation models are being used to determine both the minimum reserve and a suitable reserve for maintaining the basic ecological structure and integrity of the wetland. Thus, Tan et al. (2012) reported the minimum and suitable reserve for the Zoige Wetland to be $62.18 \times 10^{8} \mathrm{~m}^{3}$ and $66.39 \times 10^{8} \mathrm{~m}^{3}$, respectively.

\subsection{Driving forces of wetland change}

The driving forces of wetland change of the Tibetan Plateau during the 1970s-2010s have been investigated by both domestic and foreign researchers (Zhang, 2008; Qiu et al., 2009; Xing et al., 2009; Nie, 2010; Wang, 2010; Tian et al., 2011; Yao et al., 2011; Zhang, 2011). These studies have revealed the following results.

(1) Both natural and human driving forces are involved.

(2) Natural driving forces include rising temperature caused by climate warming, increased surface evaporation, increased precipitation, an acceleration in the thawing of ice and snow, and rodent damage. Natural factors are considered to have a significant influence on wetlands. For example, temperature and precipitation are amongst the main natural driving forces. Between 1960 and 2012, the rate of increase in the air temperature for the Tibetan Plateau was $0.3-0.4^{\circ} \mathrm{C} /$ decade, which is about twice the rate of global warming rate over the same period (IPCC WG II, 2014). Deglaciation of the Tibetan Plateau, which is caused by global warming, leads to an increase in lake area (Yao et al., 2010; Zhang et al., 2014a). Another study reported that the temperature of the Tibetan Plateau continued to rise at a rate above the global average between 1978 and 1999, leading to a reduction in glacier area of 
$0.44 \times 10^{4} \mathrm{~km}^{2}$ and an increase in lake area of $0.16 \times 10^{4} \mathrm{~km}^{2}$ (Zhang, 2008). Precipitation on the Tibetan Plateau showed an increasing trend, at a rate of $5.3 \mathrm{~mm} /$ decade, between 1960 and 2012. Since the 1980s, precipitation in the Himalayas has been decreasing, associated with a weakening of the Indian monsoon, whereas precipitation in the West Kunlun-Karakorum region has shown an increase associated with stronger westerlies (Yao et al., 2012). Changing patterns of rainfall have had important effects on wetland change over this period.

(3) Human driving forces include increased livestock population and intensified resource exploitation, engineering drainage, road construction, and tourism. These factors are considered dominant in particular areas. The Lalu wetland decreased at a rate of $1.04 \%$ per year as a result of the urban expansion between 1965 and 1999 (Zhang et al., 2000). The increased demand for resources that resulted from population growth led to the exploitation of a peat swamp in the Zoige Plateau. Between 1970 and 1977, $12 \times 10^{4} \mathrm{~km}^{2}$ of peat swamps were lost because of engineering drainage. Fortunately, from 1998 to 2008, the peat swamp increased by $181.42 \mathrm{~km}^{2}$ owing to the establishment of nature reserves. In addition, based on the analysis of the driving forces of wetland change, recovery measures for the wetland have been proposed, with the aim of establishing sustainable management (Zhu et al., 2003; Zhang et al., 2012b).

To conclude, the new findings from the RS-based research on the wetlands of the Tibetan Plateau can be summarized as follows (Table 3):

(1) The study area has now been extended to the whole plateau and the research scope has become more extensive.

(2) The research categories have altered from a single wetland type to diverse forms of wetlands.

(3) The research methods have changed from static monitoring to modeling and dynamic simulation.

(4) The research elements have changed from wetland types and wetland area measurements to the wetland landscape pattern and the wetland eco-environment.

(5) The research structure has evolved from a single element to an integrated system, and from two-dimensional to three-dimensional research, with more focus on the ecosystem perspective in Tibetan Plateau wetland research.

Finally, based on the review, the Tibetan Plateau wetland RS-based research has revealed the following results:

(1) In the 1990s, the wetlands of Tibetan Plateau had a significant shrinkage (Figure 2).

(2) Between 1970 and 2006, the Tibetan Plateau wetland area generally decreased at a rate of $0.23 \% / \mathrm{a}$, although the rate of change differed between particular wetland types. Using the lake wetlands as an example, between 1976 and 2009, the lake area of the inland river basins increased at a rate of 0.83\%/a; between 2003 and 2009, the depth of lakes on the Tibetan Plateau increased at a rate of $0.20 \mathrm{~m} / \mathrm{a}$; and between 1970 and 2011, the water storage of the lake wetlands increased at a rate of $2.2 \mathrm{~km}^{3} / \mathrm{a}$.

(3) Between 1990 and 2006, the landscape diversity of the Tibetan Plateau wetlands declined at a rate of $0.17 \% / \mathrm{a}$, which reflects the degradation of the entire landscape of the Tibetan Plateau wetlands.

(4) The ecosystem service value of the Tibetan Plateau wetlands comprises $14.7 \%$ of that 
for the whole plateau, which indicates their important ecological service function. Between the 1970s and the 2000s, the area of regions of "slight" and "moderate" degradation constituted $36.6 \%$ of the entire plateau, indicating that the eco-environment of the Tibetan Plateau wetlands has undergone severe deterioration.

(5) Natural driving forces are the predominant factors in Tibetan Plateau wetland change, although human driving forces are also important; human activities often play a leading role in wetland change in some areas. At the same time, the spatio-temporal changes in the wetlands are consistent with climate change - put simply, climate change leads to wetland change. Since 1990 in particular, deglaciation of the Tibetan Plateau, accompanied by more pronounced global warming, has led to a substantial increase in the lake area of the inflow regions.

Table 3 Comparison between Tibetan Plateau wetland research before and after using remote sensing

\begin{tabular}{|c|c|c|c|c|}
\hline \multicolumn{3}{|c|}{$\begin{array}{l}\text { Before using remote } \\
\text { sensing technology }\end{array}$} & \multicolumn{2}{|c|}{$\begin{array}{l}\text { After using remote } \\
\text { sensing technology }\end{array}$} \\
\hline $\begin{array}{l}\text { Research } \\
\text { item }\end{array}$ & Research content & Literature & Research content & Literature \\
\hline $\begin{array}{l}\text { Wetland } \\
\text { distribution }\end{array}$ & $\begin{array}{l}\text { Wetland investigation in } \\
\text { Tibet and Zoige, for ex- } \\
\text { ample, by field survey; } \\
\text { Observing and describing } \\
\text { the elements such as } \\
\text { wetland distribution and } \\
\text { geographical position; } \\
\text { Calculating wetland area; } \\
\text { Mapping wetland distri- } \\
\text { bution. }\end{array}$ & $\begin{array}{l}\text { Chai and } \\
\text { Jin (1963) } \\
\text { Zhao et al. } \\
(1981)\end{array}$ & $\begin{array}{l}\text { Dynamic monitoring of wet- } \\
\text { land in whole plateau by re- } \\
\text { mote sensing and field survey; } \\
\text { carrying out monitoring analy- } \\
\text { sis of wetland distribution and } \\
\text { change trends within in- } \\
\text { ter-decadal, inter-annual and } \\
\text { seasonal scales. }\end{array}$ & $\begin{array}{l}\text { Bian D et al. (2010), } \\
\text { Wang et al. (2010), } \\
\text { Yao et al. (2010), } \\
\text { Shang and Yang (2012), } \\
\text { Tan et al. (2012), } \\
\text { Tian et al. (2012) }\end{array}$ \\
\hline $\begin{array}{l}\text { Wetland } \\
\text { type }\end{array}$ & $\begin{array}{l}\text { River, lake, marsh. Marsh } \\
\text { can be classified within } \\
\text { the second class depend- } \\
\text { ing on landform, and } \\
\text { within the third class } \\
\text { depending on the domi- } \\
\text { nant plant association. }\end{array}$ & $\begin{array}{l}\text { Guan and } \\
\text { Chen } \\
(1980) \text {, } \\
\text { Zhao et al. } \\
\text { (1981), } \\
\text { Chen and } \\
\text { Fan (1983) }\end{array}$ & $\begin{array}{l}\text { River, lake, marsh, forest, } \\
\text { artificial wetland etc. Wetland } \\
\text { can be classified to the fourth } \\
\text { class; Carrying out monitoring } \\
\text { of wetland type change in } \\
\text { long-term series. }\end{array}$ & $\begin{array}{l}\text { Zhang et al. (2000), } \\
\text { Chen et al. (2001), } \\
\text { Yuan et al. (2002), } \\
\text { Zong et al. (2004), } \\
\text { Zhao et al. (2006), } \\
\text { Wang (2010), } \\
\text { Qiao et al. (2010) }\end{array}$ \\
\hline $\begin{array}{l}\text { Wetland } \\
\text { eco- } \\
\text { environment }\end{array}$ & $\begin{array}{l}\text { Mainly describing char- } \\
\text { acteristics of landform, } \\
\text { climate, animals, and } \\
\text { plants of the wetlands }\end{array}$ & $\begin{array}{l}\text { Sun et al. } \\
\text { (1987) }\end{array}$ & $\begin{array}{l}\text { Researching } \\
\text { eco-environmental change in } \\
\text { the Tibet Plateau wetland; } \\
\text { Dynamic monitoring of } \\
\text { eco-environmental change } \\
\text { from spatial pattern, health, } \\
\text { function, and service of eco- } \\
\text { system, and wetland vegeta- } \\
\text { tion biomass and wetland } \\
\text { ecowater requirements, based } \\
\text { on remote sensing. }\end{array}$ & $\begin{array}{l}\text { Zhang (2008), } \\
\text { Bian et al. (2010b), } \\
\text { Wang (2010), } \\
\text { Tan et al. (2012), } \\
\text { Song et al. (2013a) }\end{array}$ \\
\hline
\end{tabular}

\section{Research issues and future activities}

\subsection{Principal issues for RS-based research on wetlands}

At present, RS-based research on the Tibetan Plateau wetlands has focused on the following issues: (1) identification and extraction of wetland information, (2) RS-based monitoring of wetland areas and of three characteristic changes in lake regions, (3) monitoring of the landscape pattern evolution of wetlands, (4) monitoring of the ecological and environmental 
changes in wetlands, and (5) the driving forces of wetland change.

However, there are some problems with this research:

(1) In RS-based monitoring research on the wetlands of the Tibetan Plateau, remote sensing technology has been used in the development of wetland classification systems at different spatial scales with regard to overall plateau, specific region, and individual wetland type. However, a wetland classification system for the Tibetan Plateau has not yet been standardized. It is very important for future surveys of the wetlands to establish a unified classification system, which requires comprehensive knowledge of the geography, ecology, environment, hydrology, meteorology, and so on. This is also necessary during the development of remote sensing technology when establishing a classification system for the wetlands of the Tibetan Plateau.

(2) The application of computer technology is the current and future trend in remote sensing interpretation, but there are some problems regarding the accuracy of computer-based interpretation. In extracting wetland from remote sensing data for the Tibetan Plateau, the accuracy of extraction of different wetland types varies. For example, water wetland is easy to distinguish, whereas swamp wetland is easily confused with other wetland types. At the same time, although compound classification can improve extraction accuracy significantly, it has the following shortcomings: (a) In the case of a single wetland type, it does not produce a higher accuracy of classification than the use of a single classifier; (b) some classification methods, such as decision-tree classification, need the threshold parameters to be de-limited, but the threshold value is determined by subjective awareness and knowledge; (c) researchers should have broad experience of how each classifier may be combined with others.

(3) Cloud interference has become the main obstacle in achieving clear remote sensing images, in wetland identification, and in wetland extraction, especially the extraction of marsh wetland between June and September, which is recognized as the vegetation growing season. Thus, more accurate cloud removal is another problem in RS-based research that remains to be solved.

(4) The lack of a comprehensive knowledge of geography, remote sensing, ecology, environment, hydrology, meteorology, and resources science must be addressed. At present, RS-based research on the Tibetan Plateau wetlands has focused on individual issues only, such as the detection of area changes, which is the most commonly studied, and lacks a comprehensive perspective in studying the pattern evolution of wetland ecosystems, environmental changes, driving mechanisms, and so on. In addition, it is necessary to combine remote sensing techniques, mathematical modeling, and computer technology when constructing a relational model for driving forces and wetland changes in a more accurate and quantitative way.

\subsection{Future directions for RS-based research on wetlands}

The use of remote sensing technology for dynamic monitoring and wetland information extraction offers an important means for protecting and managing wetland resources, and for supplying further information where data are lacking. With the importance of the Tibetan Plateau wetlands receiving increasing attention, emphasis will in future be directed towards 
RS-based research on these wetlands. The proposed key points and future directions for RS-based research on the wetlands of the Tibetan Plateau are as follows:

(1) Current research into the wetlands must be strengthened and a wetland classification system established that is based on remote sensing of the Tibetan Plateau. Based on the correlations between the features captured by remote sensing and the characteristics of alpine wetlands, a wetland classification system must be established using remote sensing that takes into account regional adaptability, stratification, and technical operability. Some basic research work is also needed to be done, something like the scope of applicability of a wetland RS-based classification system.

(2) RS-based research into areas of the Tibetan Plateau where there is a scarcity of data must be strengthened and full advantage should be taken of RS-based monitoring with regard to multi-date, multispectral, real-time, dynamic, and repeat remote sensing images. Field investigation that can be combined with remote sensing technology is still needed.

(3) Emphasis should be placed on building a comprehensive perspective of geography, remote sensing, ecology, environment, hydrology, meteorology, and resources science. This is the key to the future of RS-based research on the Tibetan Plateau wetlands. It can be achieved by: (a) researching the response and adaptation mechanisms of the Tibetan Plateau wetland ecosystem within the context of global change, especially in terms of the differences in these mechanisms under different temporal and spatial scales; (b) linking the hydrology, ecology, meteorology, soil, and environment models to predict trends in wetland degradation; (c) revealing the similarities and differences among different regions of the Tibetan Plateau within the context of global change; (d) giving more focus to the quantitative study of the ecosystem function of wetlands and the decision support system for wetland ecosystem management; (e) studying the application of quantitative research to an analysis of the driving forces of wetland system change in the Tibetan Plateau.

(4) In terms of research technology, steps must be taken to: (a) strengthen the combination of multi-date and multispectral remote sensing images with other data, especially radar data combined with optical data; (b) reinforce the use of compound classifiers in wetland classification, and optimize the combined use of classifiers; (c) bolster research into computer-intelligent application models, such as a wetland forecasting model; and strengthen also dynamic simulation research on wetlands based on virtual reality and 3D visualization techniques, in order to analyze more rapidly and accurately the dynamic change characteristics of the Tibetan Plateau wetlands using different scales; (d) improve the technology of cloud removal; (e) strengthen the integration of RS, GIS, and GPS systems, and reinforce the construction of the Tibetan Plateau wetland information platform, in order to meet research needs in geography, remote sensing, ecology, environment, hydrology, meteorology, and resources science.

\section{References}

Bai J H, Lu Q Q, Wang J J et al., 2013. Landscape pattern evolution processes of alpine wetlands and their driving factors in the Zoige Plateau of China. Journal of Mountain Science, 10(1): 54-67.

Bai J H, Ou Y H, Xu H F et al., 2004. Advances in studies of wetlands in Qinghai-Tibet Plateau. Progress in Geography, 23(4): 1-9. (in Chinese)

Bai Y C, Wang J F, 2005. Combining multiple classifiers for thematic classification of remotely sensed data. 
Journal of Remote Sensing, 9(5): 555-563. (in Chinese)

Bian D, Bianba C R, La B et al., 2010a. The response of water level of Selin Co to climate change during 1975-2008. Acta Geographica Sinica, 65(3): 313-319. (in Chinese)

Bian J H, Li A N, Deng W, 2010b. Estimation and analysis of net primary productivity of Ruoergai wetland in China for the recent 10 years based on remote sensing. Procedia Environmental Sciences, 2: 288-301.

Chai Y, Jin S R, 1963. The type of Zoige Plateau marsh and its occurrence and development. Acta Geographica Sinica, 29(3): 219-240. (in Chinese)

Chen C Y, Fan Y Q, 1983. Rivers, lakes and water resources of the Qiangtang Plateau. Resources Science, 2: 38-44. (in Chinese)

Chen G C, Huang Z W, Lu X F et al., 2002. Characteristics of wetland and its conservation in the Qinghai Plateau. Journal of Glaciology and Geocryology, 24(3): 254-259. (in Chinese)

Chen G C, Peng M, Zhou L H, 1992. Swamp meadow of Qinghai Lake and its community characteristics. In: Collected Papers of Plateau Biology. Beijing: Science Press, 23-30. (in Chinese)

Chen Y F, 2012. Analysis of dynamic change trend of alpine wetlands in Three Rivers' Source region. Scientia Silvae Sinicae, 48(10): 70-76. (in Chinese)

Chen Y F, Chen Z M, He D K et al., 2001. Hydrographic features of Siling Co, North Tibetan Plateau. Journal of Lake Sciences, 13(1): 21-28. (in Chinese)

Chen Y Y, 1995. Study of Wetlands in China. Changchun, China: Jilin Science and Technology Publishing House. (in Chinese)

Deng M L, 2010. The Change of Landscape and Its Driving Forces in Ruoergai Plateau National Wetland Reserve in Sichuan, China. Kunming: Southwest Forestry University. (in Chinese)

Feng J M, Wang T, Xie C W, 2006. Eco-environmental degradation in the source region of the Yellow River, northeast Qinghai-Xizang Plateau. Environmental Monitoring and Assessment, 122: 125-143.

Forestry Bureau of Tibet Autonomous Region (FBTAR), 2011. Wetland Resources Investigation Report of Tibet Autonomous Region. Internal Data of Forestry Bureau of Tibet Autonomous Region, 27-28. (in Chinese)

Guan Z H, Chen C Y, 1980. River water resources in Tibet. Resources Science, 2: 25-35. (in Chinese)

He G Q, Yang G H, Feng Y Z et al., 2007. Analysis on alpine wetland's eco-system structure and function in Tibet Plateau. Agricultural Research in the Arid Areas, 25(3): 185-189. (in Chinese)

Hirota M, Kawada K, Hu Q et al., 2007. Net primary productivity and spatial distribution of vegetation in an alpine wetland, Qinghai-Tibetan Plateau. The Japanese Society of Limnology, 8: 161-170.

Huang L, Liu J Y, Shao Q Q et al., 2011. Changing inland lakes responding to climate warming in Northeastern Tibetan Plateau. Climatic Change, 109: 479-502.

International Centre for Integrated Mountain Development (ICIMOD), 2009. A manual for an inventory of greater Himalayan wetlands. International Centre for Integrated Mountain Development.

IPCC WG II, 2014. The Contribution to the IPCC's Fifth Assessment Report (WGII AR5). Cambridge: Cambridge University Press.

Jiang Q G, Li Y H, Xing Y et al., 2012. Wetland Survey Based on Remote Sensing and Ecological and Geological Environmental Effects Research in the Tibetan Plateau. Beijing: Geological Publishing House, 77. (in Chinese)

Kropacek J, Braun A, Kang S C et al., 2012. Analysis of lake level changes in Nam Co in central Tibet utilizing synergistic satellite altimetry and optical imagery. International Journal of Applied Earth Observation and Geoinformation, 17: 3-11.

Lei Y B, Yao T D, Broxton W B et al., 2013. Coherent lake growth on the central Tibetan Plateau since the 1970s: Characterization and attribution. Journal of Hydrology, 483: 61-67.

Lemly A D, Kingsford R T, Thompson J R, 2000. Irrigated agriculture and wildlife conservation: Conflict on a global scale. Environmental Management, 25(5): 485-512.

Li F P, Xu Z X, Feng Y C et al., 2013a. Changes of land cover in the Yarlung Tsangpo River basin from 1985 to 2005. Environmental Earth Sciences, 68: 181-188.

Li G Q, 2010. Distribution and degradation factors analysis of wetlands in Qomolangma national nature reserve. Chengdu: Chengdu University of Technology. (in Chinese)

Li J L, Sheng Y W, Luo J C et al., 2011. Remotely sensed mapping of inland lake area changes in the Tibetan Plateau. Journal of Lake Science, 23(3): 311-320. (in Chinese) 
Li J P, Zhang B, Zhang L et al., 2007. Current status and prospect of research on wetland monitoring based on remote sensing. Progress in Geography, 26(1): 33-43. (in Chinese)

Li L X, Zhou X M, Wang Q J et al., 1998. Wetlands of Three Rivers' Source region and its main organisms. Journal of Qinghai Environment, 8(3): 108-114. (in Chinese)

Li L, Yang X H, Zhaxi Y Z et al., 2013b. Change of the lakes in the Qiangtang nature reserve. Arid Zone Research, 30(3): 419-423. (in Chinese)

Li X Y, Ma Y J, Xu H Y et al., 2009. Impact of land use and land cover change on environmental degradation in Lake Qinghai watershed, northeast Qinghai-Tibet Plateau. Land Degradation and Development, 20: 69-83.

Li Y N, Zhao L, Zhao X Q et al., 2009. The dynamic features of alpine Potentilla fruticosa shrub meadow vegetation reflectivity. Journal of Mountain Science, 27(3): 265-269. (in Chinese)

Li Y N, Zhao X Q, Zhao L et al., 2003. Analysis of vegetation succession and climate change in Haibei alpine marsh in the Qilian Mountains. Journal of Glaciology and Geocryology, 25(3): 243-249. (in Chinese)

Li Z Q, Xu J C, Shilpakar R L et al., 2012. Mapping wetland cover in the greater Himalayan region: A hybrid method combining multispectral and ecological characteristics. Environmental Earth Sciences. doi: 10.1007/s12665-013-2512-y.

Liu B K, Wei X L, Du Y E et al., 2013. Dynamics of Qinghai Lake area based on environmental mitigation satellite data. Pratacultural Science, 30(2): 178-184. (in Chinese)

Liu R X, Liu Y J. 2008. Area changes of Lake Qinghai in the latest 20 years based on remote sensing study. Journal of Lake Science, 20(1): 135-138. (in Chinese)

Ni J R, Yin K Q, Zhao Z J, 1998. Comprehensive classification for wetlands: 1. Classification. Journal of Natural Resources, 13(3): 22-29. (in Chinese)

Nie Y, 2010. Land cover changes in MT. Qomolangma region [D]. Beijing: Graduate University of Chinese Academy of Sciences. (in Chinese)

Nie Y, Liu Q, Liu S Y, 2013a. Glacial lake expansion in the central Himalayas by Landsat images, 1990-2010. PLoS ONE, 8(12): e83973. doi:10.1371/journal.pone.0083973.

Nie Y, Zhang Y L, Ding M J et al., 2013b. Lake change and its implication in the vicinity of Mt. Qomolangma (Everest), central high Himalayas, 1970-2009. Environmental Earth Sciences, 68: 251-265.

Ozesmi S L, Bauer M E, 2002. Satellite remote sensing of wetlands. Wetlands Ecology and Management, 10: 381-402.

Phan H V, Lindenbergh R, Menenti M, 2012. ICESat derived elevation changes of Tibetan lakes between 2003 and 2009. International Journal of Applied Earth Observation and Geoinformation, 17: 12-22.

Qiao C, Luo J C, Sheng Y W et al., 2010. Analysis on lake change since ancient and modern ages using remote sensing in Dagze Co, Tibetan Plateau. Journal of Lake Sciences, 22(1): 98-102. (in Chinese)

Qiu P F, Wu N, Luo P et al., 2009. Analysis of dynamics and driving factors of wetland landscape in Zoige, Eastern Qinghai-Tibetan Plateau. Journal of Mountain Sciences, 6: 42-55.

Shang W, Yang Y X, 2012. Degradation characteristics, patterns, and processes of lakeside wetland in Napahai of northwest Yunnan Plateau, Southwest China. Chinese Journal of Applied Ecology, 23(12): 3257-3265. (in Chinese)

Shen S P, Wang J, You L J et al., 2005. Remote sensing dynamic monitoring of the Zoige marsh wetland. Acta Geologica Sichuan, 25(2): 119-121. (in Chinese)

Song C Q, Huang B, Ke L H, 2013a. Inter-annual changes of alpine inland lake water storage on the Tibetan Plateau: Detection and analysis by integrating satellite altimetry and optical imagery. Hydrological Processes. doi: 10.1002/hyp.9798.

Song C Q, Huang B, Ke L H et al., 2013b. Modeling and analysis of lake water storage changes on the Tibetan Plateau using multi-mission satellite data. Remote Sensing of Environment, 135: 25-35.

State Forestry Administration of China (SFAC), 2008. Standards of Surveying Wetland Resource of China (Tentative version). (in Chinese)

Sun G Y, 2000. Development and prospect of wetland science in China. Advances in Earth Science, 15(6): 666-672. (in Chinese)

Sun G Y, Zhang W F, Zhang J J et al., 1987. A study of ecological environment and rational exploitation of the mires in Ruoergai Plateau. Journal of Natural Resources, 2(4): 359-368. (in Chinese)

Sun H L, Zheng D, Yao T D et al., 2012. Protection and construction of the national ecological security shelter 
zone on Tibetan Plateau. Acta Geographica Sinica, 67(1): 3-12. (in Chinese)

Sun R, Zhang X Q, Zheng D, 2013. Spatial variation and its causes of water chemical property in Yamzhog Yumco Basin, South Tibet. Acta Geographica Sinica, 68(1): 36-44. (in Chinese)

Sun Y, 2009. The analysis of Zoige Plateau alpine wetland's landscape pattern based on RS and GIS. Changchun: Northeast Normal University. (in Chinese)

Sun Z G, Liu J S, Li B, 2006. The actuality, problems and sustainable utilization countermeasures of wetland resources in China. Journal of Arid Land Resources and Environment, 20(2): 83-88. (in Chinese)

Tan Y Y, Wang X, Wang Y L, 2011. Progress of wetland research in cold regions of China. Journal of Glaciology and Geocryology, 33(1): 197-204. (in Chinese)

Tan Y Y, Wang X, Li C H et al., 2012. Estimation of ecological flow requirement in Zoige alpine wetland of Southwest China. Environmental Earth Sciences, 66: 1525-1533.

The Ramsar Convention Bureau. 2000. Ramsar handbook for the wise use of wetlands.

Tian R, Cao C X, Ma G R et al., 2011. Changes and driving factors of Plateau wetlands in Maduo County. Wetland Science, 9(1): 61-68. (in Chinese)

Tian Y, Zhang X Q, Sun R, 2012. Extracting alpine lake information based on multi-source and multi-temporal satellite images and its uncertainty analysis: A case study in Yamzhog Yumco Basin, south Tibet. Journal of Glaciology and Geocryology, 34(3): 563-572. (in Chinese)

Wang C K, Wang Y S, Zhang A D et al., 2001. Wetland resources and its protection in Zoige Plateau. Bulletin of Soil and Water Conservation, 21(5): 20-23. (in Chinese)

Wang C L, 2010. The study of wetland changes in Lhasa river basin [D]. Beijing: Graduate University of Chinese Academy of Sciences. (in Chinese)

Wang F, 2008. Ecological risk assessment for the wetland aside Xizang Railway [D]. Chengdu: Southwest Jiaotong University. (in Chinese)

Wang G X, Li Y S, Wang Y B et al., 2007. Typical alpine wetland system changes on the Qinghai-Tibet Plateau in recent 40 years. Acta Geographica Sinica, 62(5): 481-491. (in Chinese)

Wang J B, Peng P, Ma Q F et al., 2010. Modern limnological features of Tangra Yumco and Zhari Namco, Tibetan Plateau. Journal of Lake Sciences, 22(4): 629-632. (in Chinese)

Wang X L, Li X Z, 1997. Advances in wetlands research. Chinese Journal of Ecology, 16(1): 58-62. (in Chinese)

Xie G D, Lu C X, Leng R F et al., 2003. Ecological assets valuation of the Tibetan Plateau. Journal of Natural Resources, 18(2): 189-196. (in Chinese)

Xing Y, Jiang Q G, Li W Q et al., 2009. Landscape spatial patterns changes of the wetland in Qinghai-Tibet Plateau. Ecology and Environmental Sciences, 18(3): 1010-1015. (in Chinese)

Xu F J, Zhou D M, Zhang Y R et al., 2014. Spatial distribution and dynamics of lake and marsh wetlands in China. Chinese Journal of Ecology, 33(6): 1606-1614. (in Chinese)

Yan L J, Qi W, 2012. Lakes in Tibetan Plateau extraction from remote sensing and their dynamic changes. Acta Geoscientica Sinica, 33(1): 65-74. (in Chinese)

Yang Y S, Chao Z H, Xuan Y et al., 2012. Monitoring methods for wetland changes of Maduo County of China based on Landsat TM data. Pratacultural Science, 29(7): 1039-1043. (in Chinese)

Yang Y X, 2002a. Main characteristics, progress, and prospect of international wetland science research. Advances in Earth Science, 21(2): 111-120. (in Chinese)

Yang Y X, 2002b. New knowledge on the progress of international wetland science research and priority field and prospect of Chinese wetland science research. Advances in Earth Science, 17(4): 508-513. (in Chinese)

Yao L, Zhao Y, Gao S J et al., 2011. The peatland area change in past 20 years in the Zoige Basin, eastern Tibetan Plateau. Frontiers of Earth Science, 5(3): 271-275.

Yao T D, Li Z G, Yang W et al., 2010. Glacial distribution and mass balance in the Yarlung Zangbo River and its influence on lakes. Chinese Science Bulletin, 55. doi: 10.1007/s11434-010-3213-5

Yao T D, Thompson L, Yang W et al., 2012. Different glacier status with atmospheric circulations in Tibetan Plateau and surroundings. Nature Climate Change, 2. doi: 10.1038/NCLIMATE1580.

Yong G W, Shi C C, Qiu P F et al., 2003. Monitoring on desertification trends of the grassland and shrinking of the wetland in Ruoergai Plateau in north-west Sichuan by means of remote-sensing. Journal of Mountain Science, 21(6): 758-762. (in Chinese)

Yuan J, Gao J X, Lv X G et al., 2002. Assessment on wetland resources in Namucuo and countermeasures for 
conservation and rational use. Resources Science, 24(4): 29-34. (in Chinese)

Zhang G Q, Xie H J, Kang S C et al., 2011b. Monitoring lake level changes on the Tibetan Plateau using ICESat altimetry data (2003-2009). Remote Sensing of Environment, 115: 1733-1742.

Zhang G Q, Yao T D, Xie H J et al., 2014a. Lakes' state and abundance across the Tibetan Plateau. Chinese Science Bulletin, 59: 3010-3021, doi: 10.1007/s1434-014-0258-x.

Zhang J C, 2008. Study on comprehensive assessment of eco-environment based on RS/GIS in the Qinghai-Tibet Plateau. Changchun: Jilin University. (in Chinese)

Zhang J C, Jiang Q G, Li Y H et al., 2007. Changes of wetland in Qaidam Basin in the past 50 years and analysis of climatic background. Journal of Jilin University (Earth Science Edition), 37(4): 752-758. (in Chinese)

Zhang J P, 2011. Changes of wetland and NPP of wetland vegetation in Damqu River Basin in source region of the Yangtze River and the influencing factors [D]. Beijing: Graduate University of Chinese Academy of Sciences. (in Chinese)

Zhang X H, Liu H Y, Baker C et al., 2012b. Restoration approaches used for degraded peatlands in Ruoergai (Zoige), Tibetan Plateau, China, for sustainable land management. Ecological Engineering, 38: 86-92.

Zhang X Q, Sun R, Zhu L P, 2012a. Lake water in the Yamzhog Yumco Basin in South Tibetan Region: Quality and evaluation. Journal of Glaciology and Geocryology, 34(4): 950-958. (in Chinese)

Zhang Y, Wang G X, Wang Y B, 2011a. Changes in alpine wetland ecosystems of the Qinghai-Tibetan Plateau from 1967 to 2004. Environmental Monitoring and Assessment, 180: 189-199.

Zhang Y L, Li B Y, Zheng D, 2014b. Datasets of the boundary and area of the Tibetan Plateau. Global Change Research Data Publishing and Repository. doi: 10.3974/geodb.2014.01.12.v1, http://www.geodoi.ac.cn/WebEn/doi.aspx?doi=10.3974/geodb.2014.01.12.v1.

Zhang Y L, Li X B, Fu X F et al., 2000. Urban land use change in Lhasa. Acta Geographica Sinica, 55(4): 395-406. (in Chinese)

Zhang Y L, Wang C L, Bai W Q et al., 2010. Alpine wetland in Lhasa river basin. China Journal of Geographical Sciences, 20(3): 375-388.

Zhao K Y, 1999. Wetlands of China. Beijing: Science Press. (in Chinese)

Zhao K Y, Wang D B, Song H Y, 1981. The preliminary research on the Tibetan Plateau marsh. Resources Science, 2: 14-21. (in Chinese)

Zhao P S, 2008. Study on the remote sensing for wetland of the Selineuo Lake in Tibet. Chengdu: Chengdu University of Technology. (in Chinese)

Zhao Y Y, Zhao X T, Zheng M P et al., 2006. The denivellation of Bankog Co in the past 50 years, Tibet. Acta Geologica Sinica, 80(6): 876-884. (in Chinese)

Zhou D M, Gong H L, Hu J M et al., 2006. Application of satellite remote sensing technology to wetland research. Remote Sensing Technology and Application, 21(6): 577-583. (in Chinese)

Zhou H M, Zeng L X, Yu G N et al., 1999. Analysis, utilization and protection of wetland resources in the northwest plateau of Sichuan Province. Southwest China Journal of Agricultural Sciences, 12: 69-74. (in Chinese)

Zhou H W, 2011. Synthetic aperture radar data based on wetland information extraction applications: To the Heima River wetlands of the west coast of Qinghai Lake case study [D]. Xining: Qinghai Normal University. (in Chinese)

Zhu L P, Xie M P, Wu Y H, 2010. Quantitative analysis of lake area variations and the influence factors from 1971 to 2004 in the Nam Co Basin of the Tibetan Plateau. Chinese Science Bulletin, 55: 1294-1303.

Zhu W Z, Zhong X H, Fan J R, 2003. The floristic features and conservation of the rare and endangered plants in Tibet. Journal of Mountain Science, 21(Suppl.1): 7-12. (in Chinese)

Zong H, Wang C S, Huang C Y et al., 2004. Diversity protection of vertebrate species and fauna analysis of Nam Co valley in Tibet, China. Journal of Chengdu University of Technology (Science \& Technology Edition), 31(5): 551-557. (in Chinese)

Zou W T, Zhang H Q, Ju H B et al., 2011. Study on highland wetlands remote sensing classification based on decision tree algorithm. Forest Research, 24(4): 464-469. (in Chinese) 